\title{
EFISIENSI PENGANGGARAN SEBAGAI FAKTOR KUNCI KEBERHASILAN DALAM PELAKSANAAN PROGRAM INOVASI DI KABUPATEN JEMBRANA PADA SEKTOR PENDIDIKAN DAN KESEHATAN
}

\author{
Gusti Putu Agus Ardika, I Gede Rudy Arsana Yasa, Komang Darma Triyasa, I \\ Made Restu Adi Putra, Putu Budhiyasa, I Gede Sandiarsa \\ Jurusan Akuntansi, Universitas Pendidikan Ganesha, Singaraja, Bali, Indonesia
}

\begin{abstract}
Abstrak
Penelitian ini bertujuan untuk menguji pengaruh penganggaran terhadap pembangunan di kabupaten Jembrana, menginvestigasi dampak yang dirasakan oleh masyarakat kabupaten Jembrana terhadap penganggaran yang diberikan oleh pemerintah, serta mengungkap kontribusi penganggaran pemerintah kabupaten Jembrana pada sektor-sektor tertentu. Penelitian dilakukan dengan menggunakan metode telaah kepustakaan. Hasil penelitian menunjukkan bahwa kontribusi penganggaran pemerintah Kabupaten Jembrana sudah dirasakan memadai bagi sektor-sektor tertentu seperti pada bidang Pendidikan, bidang Kesehatan dan bidang Perekonomian itu sendiri. Kabupaten Jembrana juga dapat dikatakan sebagai salah satu daerah yang berhasil dalam era Otonomi Daerah pasca diberlakukannya UU No. 22 Tahun 1999 tentang Pemerintahan Daerah. Hal ini dapat dicapai dikarenakan beberapa program inovasi yang telah dijalankan oleh pemerintahan kabupaten Jembrana. Dampak yang ditimbulkan dari program-prgram yang dijalankan ini berdampak positif bagi masyarakat kabupaten Jembrana. Meskipun kebanyakan dari program yang dijalankan berorientasi pada biaya sedangkan kemampuan keuangan kabupaten jembrana sangat terbatas namun program tersebut dapat berjalan dengan baik berkat Bupati kabupaten Jembrana.
\end{abstract}

Kata kunci: efisiensi penganggaran; program inovasi; kabupaten jembrana

Abstract

This study aims to examine the effect of budgeting on development in Jembrana district, investigate the impact felt by the people of Jembrana district on budgeting provided by the government, and reveal the contribution of Jembrana district government budgeting in certain sectors. The study was conducted using the literature review method. The results showed that the Jembrana district government budgeting contribution was felt adequate for certain sectors such as in the field of Education, Health and the Economy itself. Jembrana Regency can also be said as one of the regions that succeeded in the era of Regional Autonomy after the enactment of Law no. 22 of 1999 concerning Regional Government. This can be achieved because of several innovation programs that have been run by the Jembrana district government. The impact of these programs has had a positive impact on the people of Jembrana district. Although most of the programs that are run are cost-oriented while the financial capacity of Jembrana district is very limited, the program can run well thanks to the Regent of Jembrana district.

Keywords: budgeting efficiency; innovation program; Jembrana district

\section{Pendahuluan}

Anggaran merupakan suatu rencana yang disusun secara sistematis dalam bentuk angka dan dinyatakan dalam unit moneter yang meliputi seluruh kegiatan perusahaan untuk jangka waktu (periode) tertentu di masa yang akan datang. Oleh karena itu rencana yang disusun dinyatakan dalam bentuk unit moneter, maka anggaran sering kali disebut juga dengan rencana keuangan. Dalam anggaran, satuan kegiatan dan satuan uang menempati posisi penting dalam arti segala kegiatan akan dikuantifikasikan dalam satuan uang, sehingga dapat diukur pencapaian efisiensi dan efektivitas dari kegiatan yang dilakukan.Penganggaran merupakan komitmen resmi manajemen yang terkait dengan harapan manajemen tentang pendapatan, biaya dan beragam transaksi keuangan dalam jangka waktu tertentu di masa yang akan datang. 
Kabupaten Jembrana merupakan salah satu kabupaten yang berada di bagian paling barat Provinsi Bali.Perkembangannya memang tidak secepat Kabupaten lainnya, seperti kabupaten Badung dan Kota Denpasar yang berkembang sangat pesat.Namun, beberapa tahun belakangan ini Kabupaten Jembrana mampu berkembang pelan tapi pasti sesuai dengan visi dan misi Pemerintah setempat.Pembangunan yang ada di kabupaten Jembrana sudah sangat memberikan fasilitas yamg memadai dan layak bagi masyarakat seperti contoh pada pembangunan Transportasi, Jaringan Irigrasi, Sampah, Listrik, Telekomunikasi, dan Air Bersih.Pada sektor pendidikan dan kesehatan juga mempengaruhi penganggaran yang ada pada kabupaten Jembrana, dimana beasiswa pendidikan sudah sepenuhnya dirasakan oleh masyarakat Jembrana sehingga pembangunan yang di rencanakan berjalan sesuai yang diharapkan. Dimana pembangunan yang direncanakan pada saat ini seperti : 1 . Kawasan Berikat di Kelurahan Gilimanuk dan kawasan/Cluster industri penunjang pariwisata Bali, 2. Revitalisasi Pasar tradisional di seluruh Kabuaten Jembrana, 3. Memaksimalkan fungsi Gedung Soekarno yang telah ada yang sangat membutuhkan anggaran yang banyak untuk di keluarkan oleh pemerintah kabuaten Jembrana.

Pertumbuhan ekonomi Kabupaten Jembrana dapat dilihat dari PDRB (Produk Domestik Regional Bruto) Tahun 2013 dimana berdasarkan pada PDBR atas dasar harga berlaku, kontribusi masing-masing lapangan usaha mengalami peningkatan setiap tahunnya. Empat sektor besar yang memberikan kontribusi besar terhadap struktur perekonomian Kabupaten Jembrana adalah perdagangan, hotel dan restoran, disusul oleh sektor pertanian, sektor jasa serta pengangkutan dan komunkasi. Indek Pembangunan Manusia (IPM) Kabupaten Jembrana pada tahun 2013 ada pada nilai 72,69 yang berada pada urutan nomor lima di Bali setelah Kota Denpasar, Kabupaten Badung, Kabupaten Tabanan dan Kabupaten Gianyar. Tingkat harapan hidup Badan Pusat Statistik Provinsi Bali mencatat bahwa tingkat harapan hidup penduduk Jembrana pada tahun 2010 adalah 71,80 tahun, lebih tinggi dari rata-rata tingkat harapan hidup penduduk Bali 70,72 tahun. Pengelolaan keuangan daerah terus mengalami peningkatan yang tercermin dari APBD dan PAD. Pada tahun anggaran 2013 tercatat sebesar Rp. 797.854.892.374,96 dimana realisasi pendapatan sebesar Rp. 745.334.982.511,84. Capaian komponen Pendapatan Asli Daerah dimaksimalkan dengan realisasi sebesar $\mathrm{Rp}$. 68.485.482.416,06. Belanja daerah diprioritaskan untuk pembangunan Sumber Daya Manusia melalui peningkatan derajat kesehatan masyarakat, peningkatan pelayanan pendidikan serta peningkatan daya saing ekonomi. Pada tahun 2013 alokasi belanja pendidikan sebesar Rp. 293.604.088.819,03 atau $36,80 \%$ dari total belanja daerah. Sementara di bidang kesehatan Pemerintah mengalokasikan anggaran sebesar Rp. 93.661.671.100,56 atau 11,74\% dari total belanja daerah. Selanjutnya untuk peningkatan perekonomian masyarakat daerah membantu melalui penciptaan iklim usaha yang sehat bagi UMKM, memberikan dana talangan bagi KUD serta penyertaan modal kepada Jamkrida.

Berdasarkan penjelasan di atas, maka dapat dirumuskan masalah yaitu bagaimana pengaruh penganggaran terhadap pembangunan di kabupaten Jembrana, bagaimana dampak yang dirasakan oleh masyarakat kabupaten Jembrana terhadap penganggaran yang diberikan oleh pemerintah, serta apakah kontribusi penganggaran pemerintah kabupaten Jembrana sudah memadai pada sektor-sektor tertentu.

\section{Hasil dan Pembahasan}

\subsection{Sejauh mana pengaruh penganggaran terhadap pembangunan di Kabupaten Jembrana.}

Saat ini, Kabupaten Jembrana dikenal sebagai salah satu Daerah yang dianggap berhasil dalam era Otonomi Daerah pasca diberlakukannya UU No. 22 Tahun 1999 tentang Pemerintahan Daerah.Hal ini dikarenakan sejumlah program inovasi yang digulirkan oleh Pemerintah Kabupaten Jembrana yang terbukti mampu mengangkat derajat perekonomian dan kehidupan masyarakatnya. Sebut saja program inovasi di bidang pendidikan melalui pembebasan biaya pendidikan tingkat SD sampai SMU Negeri serta beasiswa untuk siswa SD sampai SMU Swasta; di bidang kesehatan melalui Jaminan Kesehatan Jembrana (JKJ) yang memberikan kebebasan akses masyarakat untuk berobat secara gratis pada PPK 1 
baik negeri maupun swasta yang memiliki kerja sama dengan Badan Pelaksana JKJ; serta di bidang ekonomi melalui Program Dana Bergulir dan sejumlah program lain yang digulirkan dalam upaya meningkatkan daya beli masyarakat Jembrana.

Merupakan hal yang menarik untuk mengetahui strategi di balik kesuksesan Pemerintah Kabupaten Jembrana dalam melaksanakan program-program inovasi tersebut dikaitkan dengan keterbatasan kemampuan keuangan daerahnya.Sebagaimana diketahui, Kabupaten Jembrana merupakan salah satu Kabupaten yang memiliki kemampuan keuangan relatif lebih rendah dibandingkan dengan Kabupaten lainnya di Propinsi Bali. Hal ini dapat dilihat dari Pendapatan Asli Daerah (PAD) Kabupaten Jembrana yang hanya sebesar Rp 11,05 milyar di tahun 2003, Rp 11,55 milyar di tahun 2002, Rp 5,54 milyar di tahun 2001 dan Rp 2,55 milyar di tahun 2000 dengan sumber penghasilan utama berasal dari pajak. Tulisan ini berusaha untuk memaparkan strategi efisiensi anggaran yang dilakukan oleh Pemerintah Kabupaten Jembrana dibawah kepemimpinan Bupati I Gede Winasa (2000-2005) sebagai salah satu faktor kunci keberhasilan dalam pelaksanaan program-program inovasi yang digulirkannya, khususnya di bidang pendidikan, kesehatan, dan perekonomian. Pengetahuan dan pemahaman akan strategi efisiensi anggaran yang dilakukan oleh Pemerintah Kabupaten Jembrana ini, diharapkan dapat menjadi lesson learned dan inspirasi bagi Pemerintah Daerah lainnya di Indonesia dalam menggulirkan program sejenis di Daerahnya masing-masing. Sejauh ini sampai tahun 2016 penganggaran dikatakan membaik dari yang dulu sehingga pada saat ini masyarakat Kabupaten Jembrana memiliki kelebihan sendiri dalam mengatur pengelolaan keuangannya yang sangat sederhana sehingga bisa diterima oleh masyarakat yang merasakan pembangunan

\subsection{Dampak yang dirasakan oleh masyarakat Kabupaten Jembrana terhadap penganggaran yang diberikan oleh pemerintah.}

Dampak yang dirasakan oleh masayarakat sangat jauh dari kesempurnaan pemerintah Kabupaten Jembrana dalam penyelenggaraan atau pengelolaan keuangan yang di lakukan oleh Bapeda.Dari sejumlah faktor tersebut, efisiensi dan efektivitas birokrasi merupakan faktor yang sangat dominan dan menentukan selain tentu saja peranan yang besar dari Bupati.Hal ini dapat dilihat dari kenyataan yang ada di lapangan bahwa sebagian besar program inovasi sangat berorientasi pada biaya (cost centered program) sementara kemampuan keuangan Pemerintah Kabupaten Jembrana sangat terbatas.Karenanya, strategi yang dilakukan oleh Pemerintah Kabupaten Jembrana adalah melalui program efisiensi pembangunan di semua sektor dalam penyelenggaraan pemerintahan. Sehingga penganggaran yang diberikan pada masyarakat bisa sesuai yang diharapkan karena dapat meningkatkan kualitas kinerja dari masyarakat yang sudah memberikan jerih payahnya pada pembangunan yang realisasikan cukup memadai pada sektor yakni :

a. Meningkatkan kualitas pelayanan bidang kesehatan, pendidikan dan sosial dasar lainnya.

Meningkatkan kualitas sumber daya manusia adalah dengan meningkatkan derajat kesehatan masyarakat dan kualitas pendidikan. Pemerintah berupaya meningkatkan kualitas pelayanan dengan memanfaatkan teknologi modern, serta meningkatkan aksesibilitas dalam bidang kesehatan, pendidikan dan sosial dasar lainnya dalam menyiapkan generasi penerus yang cerdas, terampil, mandiri dan berwawasan, sehingga mampu mengahadapi perubahan serta perkembangan kemajuan zaman.

b. Meningkatkan kuantitas dan kualitas sarana dan prasarana publik dengan memperhatikan kelestarian lingkungan.

Tersedianya sarana dan prasarana publik baik secara kuantitas maupun kualitas yang baik, seperti prasarana jalan, jembatan, irigasi, dan lainlainnya. Peningkatan ketersediaan infrastruktur akan dapat mempercepat proses pertumbuhan ekonomi serta meningkatkan kualitas layanan masyarakat.

c. Meningkatkan ketentraman dan ketertiban umum dalam kehidupan bernegara dan bermasyarakat.

Mewujudkan kesejahteraan masyarakat dalam arti luas di antaranya adalah terpenuhinya rasa aman, damai, dan tentram dalam kehidupan masyarakat.Hal ini dapat diwujudkan melalui penegakkan peraturan dan adanya kepastian hukum.Dengan 
demikian suasana kehidupan masyarakat yang saling menghargai, toleransi dan saling menjaga kerukunan diharapkan dapat terwujud.

\subsection{Kontribusi penganggaran pemerintah Kabupaten Jembrana pada sektor pendidikan dan kesehatan yang sudah memadai pada pembangunannya.}

Pada bidang ini kontribusi penganggaran pemerintah Kabupaten Jembrana sudah dirasakan memdai bagi sektor-sektor tertentu seperti pada bidang Pendidikan, bidang Kesehatan dan bidang Perekonomian itu sendiri. Dimana pembangunannya sudah dirasakan juga yakni pada bidang seperti berikut :

a. Bidang Pendidikan

Dalam bidang pendidikan, terdapat 5 (lima) program inovasi, yaitu pembebasan biaya sekolah SD - SMU Negeri dan program beasiswa untuk siswa SD - SMU Swasta; pembangunan/perbaikan gedung sekolah; pemberian beasiswa kepada guru untuk melanjutkan pendidikan; peningkatan kesejahteraan guru melalui penambahan insentif tambahan; serta penyelenggaraan sekolah kajian. Pembebasan biaya sekolah Pembebasan iuran wajib pada sekolah ini dilaksanakan sejak tahun Anggaran 2001 hingga kini. Program pembebasan iuran sekolah dilakukan terbatas hanya pada sekolah-sekolah negeri dari SD, SMP sampai SMU.Sedangkan untuk sekolah-sekolah swasta program yang dilakukan adalah pemberian beasiswa kepada siswa yang dimulai sejak tahun 2003. Program pembebasan iuran sekolah dilaksanakan mulai tahun 2001 dengan alokasi dana untuk subsidi SPP pada tahun 2001 sebesar Rp. 3.126.114.000,-, tahun 2002 sebesar Rp. 3.473.460.000,-, tahun 2003 sebesar Rp. 3.859.400.000,-, dan tahun 2004 sebesar Rp. 4.288.112.000,-. Sedangkan program pemberian beasiswa kepada siswa di sekolah swasta akan dibiayai dengan jumlah masing-masing Rp. 7.500,- per siswa untuk SD, Rp. 12.500,per siswa untuk SMP dan Rp. 20.000,- per siswa untuk SMU. Jumlah alokasi dana untuk untuk program beasiswa tahun 2003 adalah Rp. 181.380.000,- dengan 1.063 Siswa dan tahun 2004 Rp. 255.675.000,- untuk 2.735 siswa. Dana alokasi pembebasan iuran sekolah dan pemberian beasiswa langsung diberikan oleh pemerintah daerah kepada sekolah sesuai dengan jumlah siswa yang tercatat di sekolah negeri atau siswa yang tercatat sebagai penerima. Pembangunan/perbaikan gedung sekolah Pembangunan/perbaikan gedung sekolah negeri baik berupa ruang kelas baru atau ruang penunjang lainnya dilaksanakan melalui pola block grant bukan proyek seperti yang selama ini biasa dilakukan di DaerahDaerah lainnya. Pola ini dilakukan dengan mengedepankan partisipasi masyarakat melalui komite sekolah yang ada, sehingga pembangunan sarana dan prasarana pendidikan tersebut diharapkan sesuai dengan apa yang diharapkan masyarakat. Melalui pola ini, Pemerintah Kabupaten hanya memfasilitasi dan memberikan bantuan berupa dana atau material untuk bangunan yang akan direhab/buat. Pemilihan pola block grant dilakukan selain untuk memberikan ruang partisipasi kepada masyarakat juga bertujuan untuk melakukan efisiensi dan pemanfaatan dana yang lebih optimal dengan sasaran akhir yang lebih maksimal. Dengan pola ini diharapkan dapat dilaksanakan rehab/perbaikan gedung SD, SMP, maupun SMU dengan menggunakan biaya dari APBD dan DAK yang minimal namun dengan hasil yang lebih optimal. Pola block grant dilakukan melalui sebuah mekanisme yang terdiri atas sejumlah tahapan.Tahap pertama dilakukan oleh sekolah melalui komite sekolah dengan mengajukan proposal untuk melakukan perbaikan/pembangunan gedung sekolahnya. Selanjutnya pihak Dinas Dikbudpar dan instansi Pemerintah Kabupaten lain akan membentuk tim untuk mengkaji proposal yang diajukan tersebut. Hasil kajian dari tim pengkaji tersebut untuk kemudian dilaporkan kepada Bupati. Berdasarkan hasil kajian dan pengecekan lapangan yang dilakukan langsung oleh Bupati maka akan dikeluarkan sejumlah dana atau material untuk bangunan dengan standar tertentu yang ditentukan oleh Bupati. Melalui pola block grant ini telah memberikan manfaat berupa efisiensi penggunaan dana sebesar 15 - 30\% serta partisipasi masyarakat yang lebih besar melalui komite sekolah sebagai pihak yang ditunjuk untuk mengerjakan perbaikan/pembangunan gedung sekolah tersebut. Dengan pola block grant, pada tahun 2001 telah dilakukan perbaikan gedung SD sebanyak 65 unit dengan biaya Rp. 1.760.000.000,-; tahun 2002 telah dilakukan perbaikan gedung SD sebanyak 74 unit dengan 
biaya Rp. 2.112.000.000,; tahun 2003 telah dilakukan perbaikan gedung SD sebanyak 96 unit dengan biaya Rp. 2.883.120.000,-; dan tahun 2004 sebanyak 65 unit dengan biaya Rp. 2.156.500.000,-.

Peningkatan kualitas guru dilakukan dengan memberikan pendidikan dan latihan tambahan serta pemberian motivasi agar interaksi antara anak didik dan guru benar-benar harmonis dan berkualitas. Pemberian pendidikan dan latihan tambahan bagi para guru dilakukan dengan memberikan kesempatan yang seluas-luasnya bagi para guru untuk mengikuti jenjang pendidikan yang lebih tinggi melalui program D3, S1, dan S2 dengan tanggungan pembiayaan yang dibantu oleh Pemerintah Kabupaten sebesar 50\%, serta dengan memberikan penyegaran kepada para guru pada setiap liburan semester. Sementara itu, pemberian motivasi dilakukan melalui pemberian insentif tambahan berupa tunjangan bulanan, honor tambahan Rp 5.000,- per jam mengajar dan bonus Rp. 1.000.000,setiap tahun, serta melalui agenda pertemuan seluruh guru dengan Bupati yang diadakan setiap bulannya. Melalui pemberian motivasi kepada guru ini diperoleh informasi bahwa saat ini tingkat kehadiran guru mengajar di sekolah-sekolah cenderung lebih meningkat dibanding tahun-tahun sebelumnya. Sekolah kajian Sekolah kajian adalah merupakan pengembangan model pendidikan dalam mengembangkan dunia pendidikan yang lebih inovatif dan berorientasi ke depan sesuai dengan perkembangan ilmu pengetahuan dan teknologi dengan cara memadukan pola pendidikan pada sejumlah sekolah, seperti SMU Taruna Nusantara, Pola Pendidikan di Pondok Pesantren, serta Pola Pendidikan sekolah-sekolah di Jepang. Nilai lebih dari sekolah kajian ini adalah tingginya muatan disiplin anak didik yang ditanamkan seperti halnya di SMU Taruna Nusantara dan sekolah-sekolah di Jepang.Selain itu, pendidikan dan penanaman budi pekerti juga mendapatkan perhatian yang sangat serius seperti di Pondok Pesantren, yakni bagaimana hubungan antara Santri dan Kiyai, disamping pemberian keterampilan praktis serta penguasaan IPTEK sejak dini dan pengembangan SDM berwawasan global. Diharapkan melalui Sekolah Kajian ini kedepannya akan dapat mencetak anak didik yang memiliki disiplin tinggi, budi pekerti, keterampilan, IPTEK serta mempunyai wawasan global. Untuk itu, dalam rekruitmen anak didik dan guru pengajarnya dilakukan secara ketat dan disesuaikan dengan nilai yang ditetapkan dan bersifat global.Selain penekananya pada IImu Pengetahuan dan Teknologi, Sekolah kajian juga memberikan penekanan pada nilai-nilai budaya lokal sebagai pondasi dalam memasuki pergaulan global dan penguasaan ilmu pengetahuan dan teknologi.Karenanya, untuk anak didiknya juga disediakan perangkat kesenian tradisional selain perangkat kesenian modern dan perangkat teknologi terbaru. Secara garis besar, pola pendidikan dan proses belajar mengajar di Sekolah Kajian menghabiskan waktu lebih panjang dibandingkan sekolahsekolah konvensional biasa. Proses belajar dan mengajar di Sekolah Kajian dimulai Pukul 07.00 - 16.00 WITA, Pada saat istirahat, para anak didik diberikan makanan ringan dan susu sehat serta makan siang bersama dalam sebuah ruangan khusus. Dari penyelenggaraan dan pola pendidikan semacam ini, diharapkan akan melahirkan rasa solidaritas yang semakin kental diantara para peserta didik; terciptanya rasa kebersamaan, toleransi, sopan santun, serta tercipta ikatan batin yang lebih kental antara anak didik dan pendidiknya. Sekolah Kajian juga menetapkan pola asrama, yakni semua peserta didik harus tinggal di sebuah asrama yang telah disiapkan selama menempuh pendidikannya dengan diawasai oleh pengasuh. Pengasuh tidak hanya mengawasi anak asuhnya diluar jam-jam belajar, tetapi juga ikut memberikan bimbingan belajar, sehingga peserta didik akan memiliki sikap mandiri dalam menjalani proses pendidikannya. Sejauh ini, Sekolah Kajian yang telah dibangun adalah SMP Negeri 4 Mendoyo dan SMU Negeri 2 Negara.

\section{b. Bidang Kesehatan}

Dalam bidang kesehatan, program inovasi yang digulirkan adalah Program "Jaminan Kesehatan Jembrana" (JKJ) yang mulai dirintis oleh Pemerintah Kabupaten Jembrana pada tahun 2002 melalui Keputusan Bupati Nomor 572 Tahun 2002 tentang Pembentukan Tim Persiapan Jaminan Kesehatan Jembrana yang ditindak lanjuti dengan Keputusan Bupati Nomor 31 Tahun 2003 tentang Pengalihan Subsidi Pelayanan Kesehatan dan Pembentukan Badan Penyelenggara Jaminan Kesehatan Jembrana yang menandai dimulainya secara 
resmi Program JKJ. Kebijakan lainnya yang ditujukan untuk mendukung pelaksanaan Program JKJ dilakukan melalui Keputusan Bupati Nomor 84 Tahun 2003 tentang Penyerahan Obat-obatan yang Dikelola Dinas Kesehatan Kabupaten Jembrana Kepada Badan Penyelenggaraan Jaminan Kesehatan Jembrana, Keputusan Bupati Nomor 127 Tahun 2003 tentang Pembayaran Premi Jaminan Kesehatan Masyarakat Jembrana Kepada Badan Penyelenggara Jaminan Kesehatan Jembrana, dan Keputusan Bupati Nomor 559 Tahun 2003 tentang Penetapan pengelola Jaminan Pemeliharaan Kesehatan Keluarga Miskin (Gakin) Tahun 2003. Dalam pelaksanaan JKJ, Pemerintah Kabupaten Jembrana mengambil langkah untuk mengalihkan subsidi yang semula diberikan untuk biaya obatobatan RSUD dan Puskesmas menjadi diberikan kepada masyarakat melalui satu lembaga asuransi yang dibangun oleh Pemerintah yaitu Lembaga Jaminan Kesehatan Jembrana (JKJ).Subsidi ini diberikan kepada seluruh masyarakat Jembrana dalam bentuk premi untuk biaya rawat jalan tingkat pertama di unit pelayanan kesehatan yang mengikat kontrak kerja dengan Badan Penyelenggara (Bapel) JKJ. Pada saat yang bersamaan Puskesmas dan Rumah Sakit diwajibkan untuk mencari dana sendiri (swadana) untuk memenuhi kebutuhan rutinnya termasuk obat-obatan, hanya obat-obatan untuk program khusus yang dibantu oleh Pemerintah, seperti Program imunisasi, Malaria, TBC, Demam Berdarah, Diare dan kusta serta program Gizi. Program JKJ terdiri atas 3 (tiga) komponen utama, yakni (1) lembaga JKJ, (2) peserta JKJ, dan (3) PPK (pemberi pelayanan kesehatan). JKJ adalah suatu lembaga asuransi kesehatan Pemerintah Kabupaten Jembrana yang dibentuk sebagai UPT yang berada pada Dinas Kesehatan Jembrana.Lembaga ini memberikan jaminan kesehatan kepada masyarakat Jembrana dan menyalurkan subsidi Pemerintah Kabupaten Jembrana di bidang kesehatan.JKJ dipersiapkan untuk menjadi Perusahaan Daerah yang bergerak di bidang Asuransi Kesehatan.

Peserta JKJ adalah seluruh masyarakat Jembrana terutama keluarga miskin (Gakin) dan masyarakat umum yang belum terbiayai oleh sistem pelayanan asuransi kesehatan (Askes untuk PNS, Jamsostek untuk karyawan swasta, dan asuransi swadana lainnya). Melalui subsidi premi yang diberikan oleh Pemerintah Kabupaten, semua masyarakat Jembrana berhak memiliki kartu keanggotaan JKJ yang dapat digunakan untuk biaya berobat rawat jalan di setiap PPK-1 baik milik pemerintah maupun swasta (Dokter/drg/Bidan/Praktek swasta/poliklinik RS swasta kelas D) tanpa dipungut bayaran. Khusus untuk di Bidan hanya berlaku pelayanan Ante Natal Care (Pemeriksaan ibu hamil/sebelum melahirkan).Untuk PPK lanjutan, yaitu PPK-2 dan PPK-3 diikuti oleh masyarakat secara sukarela dengan preminya dibayar oleh masyarakat. Pemberi Pelayanan Kesehatan (PPK) yang mengadakan kontrak dengan lembaga JKJ terdiri antara lain Puskesmas, Pustu Pembina, RS Swasta, Poliklinik Swasta, Praktek Dokter, Praktek Dokter Gigi dan Praktek Bidan.Antara PPK JKJ dengan Lembaga JKJ mempunyai hubungan kontrak dimana kedua belah pihak memiliki hak dan kewajiban.Apabila PPK JKJ tidak memberikan pelayanan kesehatan kepada masyarakat sebagaimana tertuang dalam kontrak, maka pihak Lembaga JKJ dapat memberikan sangsi berupa skorsing selama beberapa bulan.Apabila sangsi tetap di langgar, maka pihak Lembaga JKJ dapat melakukan pemutusan hubungan kontrak.

\section{c. Bidang Perekonomian}

Dalam bidang perekonomian, terdapat 8 (delapan) inovasi program, yaitu dana bergulir; pemberian alat kerja kepada kelompok masyarakat; pelatihan dan penempatan kerja di kapal pesiar; pelatihan dan pemagangan kerja di Jepang; info bursa tenaga kerja di Dinas Kependudukan, pemberian dana talangan kepada KUD untuk membeli gabah petani; pemberian dana talangan kepada petani cengkeh; dan pembebasan Pajak Bumi dan Bangunan untuk areal pertanian. Dana bergulir Program dana bergulir Pemda Kabupaten Jembrana telah dilakukan sejak tahun 2001 dibiayai oleh dana APBD senilai 5 Milyar rupiah pertahun, sehingga sampai tahun 2004 dana bergulir tersebut telah mencapai 20 rupiah Milyar. Dana tersebut dititipkan pada Bank Pembangunan Daerah (BPD) Cabang Negara dengan rekening tersendiri. Pemberian dan pengembalian dana bergulir dilakukan melalui rekening bank tersebut. Dana ini terus terakumulasi dengan pengembalian dana bergulir 
sebelumnya sebesar $30 \%$ dari keuntungan yang diperoleh dari usaha kelompok masyarakat bersangkutan. Program dana bergulir ini juga melibatkan mobilisasi sumber daya manusia dan organisasi lokal seperti subak, subak abian, dusun/banjar, KUD, Lembaga Perkreditan Desa, Lembaga Keuangan Mikro. Kelompok-kelompok organisasi non-pemerintah ini bersama-sama dengan organisasi formal pemerintah Kelurahan dan Kecamatan melakukan penumbuhan kelompok, pembinaan, pengkajian dan pengajuan permohonan proposal kepada Pemerintah Daerah. Bahkan untuk menciptakan soliditas dan tanggung jawab kelompok masyarakat untuk mengembalikan dana bergulir yang diterima, ukuran keberhasilan atau kinerja ditentukan per wilayah Dusun. Jika dalam satu wilayah Dusun/Banjar terdapat kelompok masyarakat penerima dana bergulir yang tidak memenuhi kewajiban atau sudah jatuh tempo tidak melunasi, maka wilayah Dusun/Banjar atau lingkungan tersebut tidak bisa diusulkan untuk kelompok lainnya. Sanksi ini yang menyebabkan tanggung jawab sosial sebuah kelompok masyarakat terhadap masyarakat lainnya termasuk semua jenis bantuan baik yang bersumber dari pembangunan maupun rutin. Bahkan hal ini terjadi pada wilayah Desa/Kelurahan, dimana pada wilayah Dusun/Banjar atau Lingkungan terdapat kelompok yang tidak memenuhi kewajiban pada saat sudah jatuh tempo, maka di wilayah Desa/Kelurahan yang bersangkutan tidak dapat direalisasikan dana bergulir atau perguliran termasuk program lainnya. Keterlibatan organisasi-organisasi lokal/adat dalam pelaksanaan program dana bergulir ini memiliki peran besar terhadap tingkat pengembalian dana dan penyetoran $30 \%$ keuntungan. Tindakan yang diambil pemerintah daerah untuk melibatkan organisasi lokal/adat dalam program dana bergulir merupakan suatu inovasi yang mempertimbangkan secara mendalam kondisi sosial budaya masyarakat Jembrana yang taat pada ikatan dan sanksi-sanksi sosial. Dengan melibatkan seluruh komponan masyarakat, program dana bergulir sangat membantu pemerintah daerah pelaksanaan tugas dan pelayanan masyarakat. Mobilisasi sumber daya dengan kelompok masyarakat dengan melibatkan organisasi lokal/adat dan organisasi pemerintah merupakan instrumen yang efektif.

Pemberian alat kerja kepada kelompok masyarakat (pokmas) Program pemberian alat kerja kepada kelompok-kelompok masyarakat dilakukan dalam rangka mewujudkan peningkatan kesejahteraan masyarakat melalui sebuah proses dengan mengupayakan langkah-langkah kongkrit berupa terobosan yang berdampak pada peningkatan pendapatan masyarakat dengan sasaran utamanya adalah masyarakat berpendapatan rendah/miskin yang tersebar diseluruh pelosok Desa/Kelurahan di Kabupaten Jembrana. Program peningkatan pendapatan masyarakat tersebut dilakukan melalui 3 (tiga) strategi yaitu pengembangan sumber daya manusia, pengembangan kemampuan dalam permodalan, dan pengembangan kelembagaan masyarakat melalui sejumlah prinsip dasar, yakni:

1. Pendekatan pemberdayaan adalah Kelompok Masyarakat (Pokmas) Kepemimpinan dari masyarakat.

2. Keserasian.

3. Pendekatan Kemitraan (Pokmas sebagai mitra kerja pembangunan yang berperan serta dalam pengembalian keputusan)

4. Swadaya.

5. Belajar sambil bekerja (Pokmas dibimbing dan dibina melalui proses melakukan sendiri, mengalami sendiri dan menemukan sendiri)

6. Pendekatan Keluarga

Pemberdayaan Masyarakat melalui Pokmas ini, diarahkan untuk memberdayakan anggotanya agar memiliki kekuatan mandiri, yang mampu menerapkan inovasi (teknis, sosial dan ekonomi) memanfaatkan azas skala ekonomi dan menghadapi resiko usaha, sehingga mampu memperoleh tingkat pendapatan dan kesejahteraan yang layak. Pokmas sendiri dipilih karena pada dasarnya memiliki fungsi-fungsi sebagai kelas belajar-mengajar, sebagai unit produksi, sebagai wahana kerja sama, dan sebagai sebuah Kelompok Usaha. Agar masyarakat dapat mengakses sumber daya, permodalan teknologi tepat guna dan pasar melalui pokmas-pokmas yang ada, Pemerintah Kabupaten Jembrana telah menetapkan dan merealisir program terobosan dengan kebijakan mengalokasikan dana pembangunan atau 
rutin untuk bantuan modal kerja/usaha kepada kelompok masyarakat dengan Pola Bergulir sejak TA.2000.

Untuk mewujudkan daya guna dan hasil guna program terobosan ini, Bupati menetapkan kebijakan dengan menunjuk kantor PMD sebagai penyelenggara koordinasi dengan Dinas/Badan/Kantor terkait dan sekaligus membina manajemen dari pokmaspokmas yang ada, sementara pembinaan secara teknis dilakukan oleh Dinas/Kantor teknis terkait. Tenaga kerja: program magang dan bursa tenaga kerja Dalam rangka mengatasi kemiskinan dan pengangguran yang semakin bertambah di Kabupaten Jembrana serta dalam meningkatkan Sumber Daya Manusia sehingga menjadi lebih terampil, berkualitas dan mampu bersaing dalam era globalisasi, maka Pemerintah Kabupaten telah mencoba mengambil sejumlah langkah, diantaranya membuka kesempatan kerja di dalam negeri melalui pembentukan koperasi profesional, membuka kesempatan kerja ke luar negeri, dan melalui pemberian alat kerja kepada kelompok-kelompok masyarakat (pokmas).

Pembukaan kesempatan kerja ke luar negeri bagi masyarakat Jembrana dilakukan antara lain melalui program pelatihan dan penempatan kerja di kapal pesiar, program pelatihan dan pemagangan kerja ke Jepang, serta program bursa tenaga kerja pada Dinas Pendaftaran Penduduk Tenaga Kerja Transmigrasi dan KB. Program pelatihan dan penempatan kerja di kapal pesiar merupakan kerjasama antara Pemerintah Kabupaten Jembrana dengan pihak HRI (Hotel and Restaurant International) di Bandung.Dalam program tersebut, pendidikan dan pelatihannya dilaksanakan di Jembrana dengan biaya sepenuhnya ditanggung oleh Pemerintah Kabupaten. Pada tahun 2003 terdapat sejumlah 50 orang yang lulus seleksi untuk mengikuti program ini. Program pelatihan dan pemagangan kerja ke Jepang dilakukan melalui kerjasama antara Pemerintah Kabupaten Jembrana dengan IMM Japan dan OISCA International. Para peserta magang yang dipilih melalui seleksi yang ketat mendapatkan pelatihan terlebih dahulu selama sebulan di Baluk Negara mengenai pengenalan bahasa Jepang, budaya Jepang, dan kedisiplinan ala Jepang dan dilanjutkan dengan pelatihan selama 3 bulan di Lembang, Bandung. Biaya pelatihan dan pembiayaan lainnya sampai keberangkatan ditanggung oleh Pemerintah Kabupaten dengan sistem pengembalian kemudian setelah peserta magang melakukan magang di Jepang. Mekanisme ini dituangkan melalui Kontrak Kerja yang merupakan surat perjanjian pengembalian biaya yang dikeluarkan oleh pihak Pemerintah Kabupaten Jembrana dengan sistem cicilan selama 12 kali dan dapat ditransfer melalui rekening pihak Pemerintah Kabupaten Jembrana di Bank Pembangunan Daerah Cabang Negara. Tahun 2004, Pemerintah Kabupaten Jembrana memberangkatkan 35 orang peserta magang yang merupakan gelombang kedua dari program pemagangan kerja ke Jepang tersebut. Selain kedua program pelatihan kerja tersebut, Pemerintah Kabupaten Jembrana juga melakukan program bursa tenaga kerja bekerja sama dengan sejumlah perusahaan. Pihak perusahaan akan memberikan informasi tenaga kerja kepada Dinas Pendaftaran Penduduk Tenaga Kerja Transmigrasi dan KB, sehingga masyarakat mendapatkan informasi lowongan kerja, serta pemerintah dapat menyiapkan tenaga kerja serta bentuk-bentuk pendidikan dan latihan yang akan diprogramkan oleh Pemerintah Kabupaten.

Dana talangan Dana talangan pemberian gabah petani dilakukan dalam rangka mengatasi kesulitan petani terkait dengan murahnya harga gabah pada waktu musim panen raya. Program ini dilakukan dengan pola kemitraan antara Pemerintah Kabupaten, KUD dan Kelian Subak. Pemerintah Kabupaten memberikan bantuan dana kepada KUD yang kekurangan dana senilai Rp. 1.000.000.000,- dari APBD dan Rp 875 juta dari dana Pemerintah Pusat untuk membeli gabah petani melalui Kelian Subak. Selanjutnya Pemerintah Kabupaten membeli beras dari KUD untuk memenuhi kebutuhan beras PNS. Selain untuk untuk menanggulangi anjloknya harga gabah petani pada musim panen puncak, program ini juga bertujuan agar KUD sebagai lembaga pemasaran (tata niaga) beras/gabah dapat menampung gabah petani, dan menciptakan rasa agar masyarakat Jembrana lebih mencintai dan memanfaatkan produksi petani lokal. Sejumlah manfaat yang dirasakan dari keberadaan program ini antara lain adalah harga gabah petani yang tidak lagi anjlok meskipun pada saat musim panen puncak, KUD dapat lebih berperan sebagai lembaga pemasaran hasil pertanian utamanya gabah/beras karena mendapat bantuan dana 
dari Pemerintah Kabupaten berupa uang muka pembayaran beras bagi PNS, serta Pemerintah Kabupaten sendiri dapat memenuhi kebutuhan beras bagi PNS dilingkungannya dengan harga sesuai kesepakatan. Upaya lainnya yang dilakukan Pemerintah Kabupaten Jembrana dalam memproteksi atau memberikan perlindungan kepada para petani yang merupakan mayoritas di Jembrana adalah melalui pemberian dana talangan kepada petani cengkeh untuk menanggulangi anjloknya harga cengkeh pasca panen di pasaran. Dana talangan/dana pinjaman yang dialokasikan pada tahun 2003 sebesar Rp 1 miliar kepada 9 subak abian. Bantuan biaya tersebut diperuntukkan untuk biaya petik sehingga petani tidak menjual cengkeh basah yang dimilikinya. Jumlah Dana Talangan untuk 1 kwintal cengkeh kering sama dengan 3 kwintal cengkeh basah sebesar Rp. 500.000,-. Subsidi pembebasan pajak bumi dan bangunan (pbb)

Dalam rangka memberikan perlindungan dan stimulan kepada petani agar tetap mempertahankan lahan sawahnya dan tidak mengalihkan kepada fungsi lain maka Pemerintah Kabupaten Jembrana melakukan program pembebasan Pajak Bumi dan Bangunan untuk areal pertanian. Kebijakan ini dilakukan melalui pemberian subsidi Pajak Bumi dan Bangunan (PBB) khusus terhadap tanah sawah di Kabupaten Jembrana.Kebijakan ini dituangkan dalam Keputusan Bupati Nomor. 207 Tahun 2003 tanggal 22 April 2003 tentang pemberian subsidi pajak bumi bangunan khusus terhadap tanah sawah di Kabupaten Jembrana pada tahun 2003 yang nilainya sebesar Rp.697.928.061,-. Kebijakan ini merupakan salah satu kebijakan yang dikeluarkan untuk mendukung program Ketahanan Pangan di Kabupaten Jembrana. Kebijakan ini bertujuan untuk menekan alih fungsi lahan sawah menjadi lahan kering dan non pertanian. Jika pada lima tahun terakhir (tahun 1997 2001) rata-rata beralih fungsi sekitar 135 hektar, maka pada tahun 2002 terjadi penurunan luas lahan sawah menjadi 346 hektar, sehingga lahan sawah di Kabupaten Jembrana saat ini luasnya tinggal 7.339 hektar dari lahan semula luasnya 7.685 hektar.

\section{Simpulan dan Saran}

Berdasarkan data-data yang telah kami kumpulkan dapat disimpulkan bahwa kabupaten Jembrana dapat dikatakan sebagai salah satu daerah yang berhasil dalam era Otonomi Daerah pasca diberlakukannya UU No. 22 Tahun 1999 tentang Pemerintahan Daerah.Hal ini dapat dicapai dikarenakan beberapa program inovasi yang telah dijalankan oleh pemerintahan kabupaten Jembrana.Yang dimana program inovasi ini dapat mengangkat derajat kabupaten Jembrana secara perlahan. Beberapa program yang dijalankan oleh pemerintahan kabupaten jembrana yang dimana berfokus pada bidang pendidikan, bidang kesahatan, dan bidang ekonomi. Dampak yang ditimbulkan dari programprgram yang dijalankan ini berdampak positif bagi masyarakat kabupaten Jembrana. Meskipun kebanyakan dari program yang dijalankan berorientasi pada biaya sedangkan kemampuan keuangan kabupaten jembrana sangat terbatas namun program tersebut dapat berjalan dengan baik berkat Bupati kabupaten Jembrana. Melalui strategi yang dilakukan oleh Pemerintah Kabupaten Jembrana penganggaran yang diberikan pada masyarakat bisa sesuai yang diharapkan karena dapat meningkatkan kualitas kinerja dari masyarakat yang sudah memberikan jerih payahnya pada pembangunan yang realisasikan. Dalam kontribusi penganggaran pemerintah Kabupaten Jembrana sudah dirasakan memadai bagi sektorsektor tertentu seperti pada bidang Pendidikan, bidang Kesehatan dan bidang Perekonomian itu sendiri.

Berdasarkan hasil analisis data dan kesimpulan tentang kinerja keuangan pemerintah kabupaten jembrana penulis mencoba mengajukan beberapa saran. Saran-saran tersebuat adalah sebagai berikut

1. Pemerintah daerah harus mengoptimalkan penerimaaan dari potensi pendapatannya yang telah ada.

2. Mengingat terbatasnya jumlah dan jenis sumber-sumber pendapatan asli daerah, maka diperlukan penyerahan beberapa sumber-sumber keuangan nasional yang potensial untuk dikelola dan dipungut sendiri oleh daerah dan menjadi penerimaan PAD. 
3. Untuk mengatasi kurang serasian antara belanja rutin dan belanja pembangunan, sebaiknya pemerintah harus menetapkan standar ukuran dan patokan dalam mengambil kebijakan pembangunan agar terciptanya keserasian tersebut

4. Untuk merangsang rasio pertumbuhan, pemerintah sebaiknya mengadakan pendekatan persuasive kepada wajib pajak agar memenuhi kewajibannya melalui kegiatan penyuluhan serta melaukan langkah-langkah pengendalian lain guna menghindari timbulnya penyimpangan terhadap pelaksanaan peraturan daerah mengenai pengelolaan keuangan daerah.

\section{DAFTAR PUSTAKA}

Prasojo, Eko, Teguh Kurniawan dan Azwar Hasan., 2004., Reformasi Birokrasi dalam Praktek: Kasus di Kabupaten Jembrana., Depok: Pusat Kajian Pembangunan Administrasi Daerah dan Kota FISIP UI

2004., "Peran Kepemimpinan dalam Program Inovasi Daerah: Studi Kasus Kabupaten Jembrana"., Bisnis \& Birokrasi., Volume XII/Nomor 3/September 2004., Departemen IImu Administrasi FISIP UI

Winasa, I Gede., 2004., "Peningkatan Pelayanan Publik dan Efisiensi Birokrasi di Kabupaten Jembrana"., makalah., Seminar Sehari Kreativitas dan Inovasi Daerah dalam Penyelenggaraan Otonomi Daerah Menuju Tata Pemerintahan yang Baik., Jakarta 13 Juli 2004

http://www.jembrana.go.id

https://pustakaonline.wordpress.com/2008/03/22/efisiensi-anggaran-sebagai-faktor-kuncikeberhasilan-dalam-pelaksanaan-program-inovasi-di-kabupaten-jembrana/ 